\title{
Reproductive performances of wild male tiger shrimp Penaeus monodon post-injection of oocyte developer without eyestalk ablation
}

\section{Performa reproduksi udang windu Penaeus monodon jantan alam pascainjeksi hormon oocyte developer tanpa ablasi tangkai mata}

\author{
Dony Prasetyo $^{1}$, Asda Laining ${ }^{2 *}$, Agus Oman Sudrajat ${ }^{1}$ \\ ${ }^{1}$ Department of Aquaculture, Faculty of Fisheries and Marine Science, Bogor Agricultural University \\ Campus IPB Dramaga Bogor, West Java, Indonesia 16680 \\ ${ }^{2}$ Research Institute for Brakishwater Aquaculture and Fisheris Extention \\ Jl. Makmur Dg. Sitakka No. 129 Maros, South Sulawesi, Indonesia \\ *E-mail: asdalaining@yahoo.com
}

\begin{abstract}
The aim of this study was to evaluate the effect of oodev on the gonadal maturation and characteristic of spermatophore and spermatozoa produced by the wild male black tiger shrimp against eyestalk ablation. The treatments were two doses of oodev injection at 0.5 (OD0.5) and 1 (OD1.0) $\mathrm{mL} / \mathrm{kg}$ of body weight and a control was eyestalk ablation (AB). The male stock of tiger shrimp used was from wild with body weight ranged from 55-85 g, stocked into three of 10 tonnages concrete tanks with density of 25 males/tank. Oodev injection was applied for two times with one week interval. Tiger shrimp of OD0.5 group produced the highest number of gonadal maturing which was $84 \%$ followed by $\mathrm{AB}(68 \%)$ and OD1.0 (64\%). Oodev injection was able to shorten the time required for spermatophore maturation at maturation phase which happened simultaneously within 7 days post injection compared to that of ablated males. Positive correlation $(\mathrm{R} 2=0.612)$ was detected between the shrimp weight and weight of spermatophore of the tiger shrimp while correlation between spermatophore weight and number of spermatozoa was relatively low $(\mathrm{R} 2=0.415)$. Total fatty acid tented to be higher in males injected with oodev compared to ablated males. Concentration of arachidonic acid in the muscle of male stock in OD1.0 group was extremely low of $0.0037 \%$ of total lipid compared to AB $(0.3190 \%)$ and OD0.5 $(0.2806 \%)$. Oodev injection at the dose of $0.5 \mathrm{~mL} / \mathrm{kg}$ of tiger shrimp could improve the number of males stock producing spermatophore compared to eyestalk ablation. Simultaneously matured-spermatophore of wild male tiger shrimp within short time could be achieved through oodev injection.
\end{abstract}

Keywords: oodev, spermatophore, reproduction, tiger shrimp

\begin{abstract}
ABSTRAK
Tujuan penelitian ini adalah mengevaluasi efek hormon oodev terhadap pematangan gonad dan karakter spermatofor dan spermatozoa yang dihasilkan oleh induk udang windu jantan alam dibandingkan dengan teknik ablasi tangkai mata. Perlakuan yang dicobakan adalah dua dosis injeksi oodev yaitu $0,5(\mathrm{OD} 0,5)$ dan $1(\mathrm{OD} 1,0) \mathrm{mL} / \mathrm{kg}$ bobot tubuh dan kontrol yaitu ablasi tangkai mata $(\mathrm{AB})$. Induk udang windu jantan yang digunakan berasal dari alam berbobot antara $55-85 \mathrm{~g}$, ditebar dalam tiga bak pematangan gonad berkapasitas 10 ton dengan kepadatan 25 ekor/ bak. Injeksi oodev dilakukan dua kali dengan interval satu minggu. Induk udang windu pada OD0,5 menghasilkan jumlah induk matang gonad tertinggi yaitu 84\%, diikuti oleh AB (68\%) dan OD1 (64\%). Injeksi oodev mampu mempersingkat masa pematangan spermatofor pada fase maturasi dan pematangan tersebut terjadi secara simultan setelah 7 hari pascainjeksi dibandingkan dengan induk yang di ablasi. Korelasi positif $(\mathrm{R} 2=0,612)$ dideteksi antara bobot tubuh dan bobot spermatofor induk udang windu, sedangkan korelasi antara bobot spermatofor dan jumlah spermatozoa relatif lemah $(\mathrm{R} 2=0,415)$. Total asam lemak daging cenderung lebih besar pada induk udang windu jantan yang diinjeksi oodev dibandingkan yang diablasi. Konsentrasi arachidonic acid dalam daging induk yang diinjeksi OD1 sangat rendah sebesar 0,0037\% dari lemak dibandingkan AB $(0,3190 \%)$ dan OD0,5 $(0,2806 \%)$. Injeksi oodev pada dosis $0,5 \mathrm{~mL} / \mathrm{kg}$ udang windu dapat meningkatkan jumlah induk yang menghasilkan spermatofor dibandingkan ablasi tangkai mata. Pematangan gonad udang windu jantan alam secara simultan dan singkat dapat dilakukan melalui injeksi oodev.
\end{abstract}

Kata kunci: oodev, spermatofor, reproduksi, udang windu 


\section{INTRODUCTION}

Demand on broodstocks of tiger shrimp for commercial hatcheries so far still relies on capture from the wild. Wild broodstocks in general have several good attributes, however their quality vary and they are claimed to be pathogenic carrier which transmitte diseases into aquaculture system (Coman et al., 2006). Production of tiger shrimp broodstock from aquaculture still has several constrains including low number of maturing spawner, the final stage of maturation is not as good as the wild spawner, un-sincronized gonad maturation between male and female stocks, low mating rate, delayed spawning time, low hatching rate and low survival of post-larvae (Marsden et al., 2008; Uawisetwathana et al., 2011; 2013; Laining et al., 2014; Laining et al., 2015).

In commercial hatcheries, the common technique used to stimulate the development of gonadal maturation of crustaceans including tiger shrimp is eyestalk ablation. Ablation is a technique to cut one of the spawner's eye in order to reduce production of gonadal inhitibing hormones. Although ablation can accelerate the process of gonadal development of tiger shrimp, it has several disadvantageous such as stimulating a strong stress even mortality of the spawner, destroying physiological function, decreasing gamet quality, and against to the animal welfare (Wongprasert et al., 2006; Sainz-Hernández et al., 2008; Uawisetwathana et al., 2011). Furthemore, the use of ablated tiger shrimp generally only for 3-4 maturation cycles before being discarded. One alternative to ablation which has been developed for tiger shrimp gonadal maturation is through hormonal manipulation (Laining et al., 2015).

Several hormones functioning in reproductive system of vertebrate have also been detected in crustacean. Huang et al. (2008) stated that FSHLH-likesubstances was detected in brain and thoracic ganglion of swimming crab, Portunus trituberculatus and GTH-like substances was also detected in the same organs of mud crab, Scylla paramamosain (Ye et al., 2009). Moreover, dopamine has been identified in eyestalk of giant prawn, Macrobrachium rosenbergii (Tinikul et al., 2008) and shrimp (Chang et al., 2007; Babu et al., 2013; Sukthaworn et al., 2013). Based on these findings, it is suspected that crustacean including tiger shrimp will response to hormone stimulation such as gonadotropin and antidopamine.

Oocyte developer (oodev) is a hormone premix containing PMSG (pregnant mare serum gonadotropin) and antidopamin (AD). PMSG is a glicoprotein hormone secreted by trophoblast cells of horse containing FSH and LH (Hafez \& Hafez, 2000). Antidopamine is a neurotrasmitter which inhibits activity of dopamine receptor (Dufour et al., 2010). Oodev has been applied to stimulate gonadal development of several species such as eel (Sudrajat et al., 2014), and catfish (Nainggolan et al., 2014). The positive effect of this hormone has been also observed on vaname shrimp (Akbar et al., 2015) and female stock of tiger shrimp (Laining et al., 2015).

Sudrajat et al. (2014) has injected eel, Anguilla bicolor using combination of oodev and recombinant growth hormone $(\mathrm{rGH})$ at combined dose of $20 \mathrm{IU}$ PMSG/kg, $100 \mathrm{mg}$ $\mathrm{AD} / \mathrm{kg}$ and $10 \mu \mathrm{g} \mathrm{rGH} / \mathrm{kg}$ to improve gonadal maturation up to $100 \%$ with a more matured gamet stage. Combination oodev at $15 \mathrm{IU}$ and supplementation of 3\% Spirulina sp in diet fed to catfish could faster the oocite development and viability of egg and larvae (Nainggolan et al., 2014). Akbar et al. (2015) applied oodev to inject male vaname shrimp at dose of in order to $0.5 \mathrm{~mL} / \mathrm{kg}$ enahnced the gonadal maturation with a improved reproductive performances compared to ablation. Application of oodev on female tiger shrimp has been also carried-out through three times injection at dose of $3 \mathrm{~mL} / \mathrm{kg}$ resulting a higher percentage of maturing broodstock than that of ablation, but still with a lower hatching rate Laining et al. (2015).

The objective of this study was to evaluate the effects of oodev hormone on gonadal maturation and characteristic of spermatophore and spermatozoa produced by wild tiger shrimp, Penaeus monodon male against eyestalk ablation.

\section{MATERIALS AND METHODS}

\section{Quarratine and acclimatization of wild male tiger shrimp}

Male tiger shrimp were obtained from Makassar Strait of South Sulawesi. As much as 75 male stocks were selected with weight ranged from $50-70 \mathrm{~g}$ without morphological abnormality. The male stock were acclimatized in quarratine room for $2-4$ weeks before being transferred to maturation tank. During culture period, males stock were fed freshfeed four times a day with squid and bivalve Anadara granosa at rate of $2-3 \%$ of dry basis shrimp biomass. Water supply was a filtrated and sterilized sea water.

Water quality was measured in every three 
days with temperature at $28.3 \pm 0.2^{\circ} \mathrm{C}($ mean $\pm \mathrm{SD})$, salinity at $30.1 \pm 0.3 \mathrm{~g} / \mathrm{L}$, and dissolved oxygen at $5.63 \pm 0.17 \mathrm{mg} / \mathrm{L}$. Every day all tanks were syphoned and exchanged the water at level of $60 \%$. After four weeks acclimatization, the male stocks were transferred into three of 10 tonnages maturation concrete tanks. The tanks were set with aeration system and flow-through water supply at rate of $10 \mathrm{~L} /$ minutes. Photoperiod was arranged with 12-h light and 12-h dark.

\section{Injection of oodev hormone and eyestalk ablation}

The treatments were three doses of oodev hormone at $0(\mathrm{AB}) ; 0.5(\mathrm{OD} 0.5)$; and $1.0(\mathrm{OD} 1.0)$ $\mathrm{mL} / \mathrm{kg}$ of shrimp weight. This experiment was designed without replication due to the limited maturation tanks. Application of oodev was through injection following the protocol applied by Laining et al. (2015) and shrimp without injection but ablated was the control (AB). Prior to treatments, male was individually eye-tagged for recognition and further randomly stocked into three of 10 tonnages concrete tanks with density of $25 \mathrm{males} / \mathrm{tank}$ for each treatment. Injection was performed twice with one week interval ( $\mathrm{H}-0$ nd H-7, respectively). Male shrimp were injected using $0.5 \mathrm{~mL}$ syringe at the $2^{\text {nd }}$ or $3^{\text {th }}$ segment of dorsal. At the same time of $2^{\text {nd }}$ injection, other bacth of the males were ablated for control group.

\section{Observation on spermatophore and spermatozoa}

Unlike tiger shrimp female stock, gonadal development of male stock including testes and spermatophore is not easy to evaluate based on external appeareance. A technique to assess spermatophore development has been developed by artificially releasing the spermatophore out of ampulla terminale. The males which released ther spermatophore through electrical shock are assumed as a matured stock (Laining et al., 2016).

Technique of artificially ejaculation applied in the present study was by electrical shock using transformer set up at $5 \mathrm{~mA}$ and $8-12 \mathrm{~V}$ following the protocol applied by Lante and Laining (2016). The transformer was connected with an electrode placed near the gonophores at the base of the 5th pereiopodsa applied usually for two seconds. The eletrical shock stimulates contraction surrounding the terminal ampullae expelling a single spermatophore from each gonophore. The electrical shock to release the spermatophore was applied three times at 7,14 , and 21.days from the
DOI: 10.19027/jai.16.1.76-82

last injection. If a male released spermatophore at the first electrical shock, it was claimed to be at maturation stage and if the same male again released spermatophore at the second and third electrical shock, it was categorized to be at $1^{\text {st }}$ re-maturation and $2^{\text {nd }}$ re-maturation, respectively (Laining et al., 2016). Percentage of male stock maturing is calculated based on number of males releasing spermatophore in each of the maturation stage divided by number of injected males. Furthemore, it was also observed the treatment effect on the time required by the male to release the spermatophore or to mature post-oodev injection. If a male matured at the first electrical shock or at 7 days post-oodev injection then the male required 7-days (H-7) for spermatophore maturation. Accordingly, if a male matured at second and third electrical shock, then the male required $14(\mathrm{H}-14)$ and $21(\mathrm{H}-21)$ days for spermatophore maturation.

To assess the characteristic of spermatophore, the released spermatophore was weight using electrical balance (Sartorius, Germany), homogenized with micro-homogenizer (Radnoti, USA) and then added with $0.9 \mathrm{~mL}$ calciumfree saline solution (Jiang et al., 2009). Trypan blue of $0.1 \%$ was added at level of $0.1 \mathrm{~mL}$ to improve the contrast between the cell and dilution. Number of spermatozoa was calculated using haemocytometer under microscope at $400 \times$ (Olympus DP21, Japan). The spermatozoa cells were snapped and counted the number using ImageJ software. Characterization of the sperm cell was observed for the number of total sperm cell and percentage of normal cell. Criteria for abnormal spermatozoa was evaluated according to Jiang et al. (2009) and Leelatanawit et al. (2014).

\section{Histological and bio-chemical analysis}

For histological assessment, three male stocks representing each groups was randomly selected to be dissected and taken their reproductive organ including testes, vas deferens and ampulla terminale. Samples were taken at H-14, H-21, and $\mathrm{H}-28$. All organ samples was preserved in Davidson solution and after 24-h the preservative solution was changed with $70 \%$ alcohol prior to histology. Hematoxilin-eosin was used for staining and observed under microscope (Olympus DP21, Japan).

Proximate analysis and analysis of fatty acid content in muscle was carried out to determine the effect of eye stalk ablation on physiological 
metabolism besides on reproduction. The muscle was dried in oven at $60^{\circ} \mathrm{C}$ (Memmert, Germany) and stored in $-20{ }^{\circ} \mathrm{C}$ before being analyzed. Proximate analysis was performed according to AOAC (1999) and profile of fatty acid was detected using gas chromatografi (GC, FID Perkin Elmer Clarus 680, USA).

\section{Statistical analysis}

Single data on percentage of maturing male was descriptively analyzed. Effect of treatments on spermatophore weight, number of spermatozoa and percentage of normal sperm cell was analyzed by one-way ANOVA single factor with multiple comparisons evaluated using LSD test at 0.05 of the level of significance using software SPSS version 21 (SPSS, IBM, US). Relationship between body weight, spermatophore weight and number of sperm cell was determined linear regression linier using Microsoft Excel 2013.

\section{RESULTS AND DISCUSSION}

\section{Results \\ Number of male tiger shrimps releasing spermatophore}

Mean weight and number of males releasing spermatophore after electrical shock post-oodev injection is presented in Table 1. Number of males releasing their spermatophores for the fist time (maturation) was the highest at OD0.5 of 21 males or $68 \%$ of the oodev injected males. At OD1.0, males releasing spermatophore was 16 males $(64 \%)$ relatively similar to $\mathrm{AB}$ which was $68 \%$. At the $1^{\text {st }}$ re-maturation, number of males releasing spermatophore was extremely different from maturation stage where at $\mathrm{AB}$ group was found 9 males (36\%) and at the two dosages of the oodev injection were found only $12 \%$. Furthermore, at the $2^{\text {nd }}$ re-maturation, the males releasing spermatophore was only observed one male in $\mathrm{AB}$ group.

Table 2 presents the number of males releasing their spermatophores for the first times (maturation) after oodev injection based on the time required for maturation of the spermatophore. All male stoks injected with OD0.5 matured at $\mathrm{H}-7$ or $100 \%$ of 21 males required 7 days to release their spermatophores, followed by OD1.0 of $94 \%$ ( $15 \%$ of 16 maturing males). For $\mathrm{AB}$ group, number of maturing males at $\mathrm{H}-7$ was 8 males or $47 \%$ of 17 maturing males). Males injected with oodev generally could mature at $\mathrm{H}-7$ however for the following days of $\mathrm{H}-21$ only one male re-matured. In contrast, it was still found maturing males at $\mathrm{H}-14$ and $\mathrm{H}-21$ for $\mathrm{AB}$ group which was 29 and $24 \%$, respectively (Table 2 ).

\section{Characteristic of spermatophore and spermatozoa cell of tiger shrimp}

Spermatophore weight, number of spermatozoa cell and percentage of normal spermatozoa in two spermatophore sacs of each individual male tiger shrimp were found indentic between the right and left side. Therefore, the data provided in Table 3 were only for one sac of the spermatophore of individual male from all groups. Mean spermatophore weight, number of spermatozoa and percentage of normal sperm at maturation stage in $\mathrm{AB}$ group was not significantly different $(P>0.05)$ from other two groups.

Data on spermatophore weight and number of spermatozoa produced by male tiger shrimps at three maturation cycles are presented in Table 4. Mean spermatophore weight released by males at $\mathrm{H}-7$ did not significantly $(\mathrm{P}>0.05)$ differ among three treatments. Similarly, number of spermatozoa within spermatophore was not influenced by both oodev injection and ablation. Since the spermatophore produced by male stocks at $\mathrm{H}-14$ was only occurred at $\mathrm{AB}$ group the statistical analysis was not performed for maturation stage. Accordingly, males injected with OD0.5 did not release spermatophore at $\mathrm{H}-21$. From Table 4, it is showed that ablated males produced bigger spermatophore at $\mathrm{H}-7$ and $\mathrm{H}-14$ than that of produced at H-21. However, number of the normal spermatozoa did not differ based on the time required for spermatophore maturation.

Based on linear regression between body weight and spermatophore weight released by tiger shrimp at maturation and 1st re-maturation, there was a positive relationship between body weight and spermatophore weight with the coefficient determination $\left(\mathrm{R}^{2}\right)$ of the treatments ranged from $0.57-0.60$. The same $R^{2}$ in all groups indicated that the relationship between shrimp weight and spermatophore weight of tiger shrimp was not influenced by both ablation and oodev injection. When all data were pooled, the $\mathrm{R}^{2}$ value become higher of 0.612 (Figure 1).

Relationship between spermatophore weight and number of spermatozoa was also carried-out

for each treatment and pooled data. Figure 2 showed that there was no positive relationship between those two reproductive parameters with $\mathrm{R}^{2}$ value below 0.5 and the values ranged from 
0.4-0.48 implying that the relationship was not affected by the neither abalation nor oodev injection. Even when data for all groups were pooled the $\mathrm{R}^{2}$ value only 0.4147 .

Proximate composition profile of fatty acid in muscle of male tiger shrimp

Proximates composition of muscle of the males at the end of assessment are presented in Table 5. There were no differences on proximate composition of the muscle among the three groups, except for crude protein in which shrimp injected with OD1.0 was likely to have higher protein content in the muscle compared to $\mathrm{AB}$ and OD0.5. Fatty acid (FA) profile of male tiger shrimp before injection ( $\mathrm{H}-0)$ and at the end of assessment $(\mathrm{H}-21)$ is presented in Table 6. Total fatty acid in muscle of tiger shrimp prior to treatments was generally lower than those after treatments. Ablated male stocks contained lower total fatty acid of $2.2600 \%$ of lipid compared to OD0.5 and OD1.0 which were $2.6344 \%$ and $2.6449 \%$, respectively. Injection of OD1.0 resulted in an extremely low arachidonic acid (ARA) content in muscle which was $0.0037 \%$ of lipid than that of $0.2632 \%$ for OD0.5 and $0.3190 \%$ for control AB.

\section{Reproductive organ of male tiger shrimp}

Reproductive organ of male tiger shrimp was identified to be relatively similar to reproductive organ of other penaeoidens in general consisting of five pairs lobul of testes connected to vas deferens and it terminate in ampulla terminale. Spermatophore developed inside the ampulla terminale (Figure 3A). Based on histological analysis, it was indicated that each of the testes lobul consisting of seminiferous tubules where germinal cell exist (Figure 3B and 4C). Figure B is the light micrograph of testes lobul consisting

Table 1. Mean weight and number (percentage) of males releasing the spermatophores post-oodev injection

\begin{tabular}{cccccc}
\hline \multirow{2}{*}{ Treatment* } & $\begin{array}{c}\text { S Male } \\
\text { stock } \\
\text { (shrimp) }\end{array}$ & Mean weight $(\mathrm{g})$ & \multicolumn{3}{c}{ No. of male releasing spermatophore (shrimp) } \\
\cline { 4 - 6 } & 25 & $74.40 \pm 10.22$ & $17(68 \%)$ & $9(36 \%)$ & $1(4 \%)$ \\
AB & 25 & $63.84 \pm 12.20$ & $21(84 \%)$ & $3(12 \%)$ & 0 \\
OD0.5 & 25 & $66.08 \pm 11.73$ & $16(64 \%)$ & $3(12 \%)$ & 0 \\
OD1.0 & 25 & $1^{\text {st }}$ & Maturation & \\
\hline
\end{tabular}

*AB =eyestalk ablation; OD0.5 = injection of $0.5 \mathrm{~mL}$ oodev $/ \mathrm{kg}$; OD1.0 = injeksi $1.0 \mathrm{~mL} / \mathrm{kg}$

Table 2. Number of male tiger shrimps maturing post-oodev injection based on the time required to relesease the spermatophore

\begin{tabular}{ccccc}
\hline \multirow{2}{*}{ Treatment* } & \multirow{2}{*}{$\begin{array}{c}\text { Male stock } \\
\text { (shrimp) }\end{array}$} & \multicolumn{3}{c}{$\begin{array}{c}\text { No of male maturing based on the time required to release } \\
\text { spermatophore (shrimp) }\end{array}$} \\
\cline { 3 - 5 } & & $\mathrm{H}-7$ & $\mathrm{H}-14$ & $\mathrm{H}-21$ \\
\hline $\mathrm{AB}$ & 17 & $8(47 \%)$ & $5(29 \%)$ & $4(24 \%)$ \\
OD0.5 & 21 & $21(100 \%)$ & 0 & 0 \\
OD1.0 & 16 & $15(94 \%)$ & 0 & $1(6 \%)$ \\
\hline
\end{tabular}

*AB =eyestalk ablation; OD0.5 = injection of $0.5 \mathrm{~mL}$ oodev $/ \mathrm{kg}$; OD1.0 = injeksi $1.0 \mathrm{~mL} / \mathrm{kg}$

Table 3. Spermatophore weight, number of spermatozoa (per spermatophore sac) and number of normal sperm cells of tiger shrimp post-injection of oodev at maturation stage

\begin{tabular}{|c|c|c|c|c|}
\hline \multirow{2}{*}{$\begin{array}{l}\text { Maturation } \\
\text { stage }\end{array}$} & \multirow{2}{*}{ Parameter } & \multicolumn{3}{|c|}{ Treatment* } \\
\hline & & $\mathrm{AB}$ & OD0.5 & OD1.0 \\
\hline \multirow{3}{*}{ Maturation } & Spermatophore weight (g) & $0.0533 \pm 0.0114 \mathrm{a}$ & $0.046 \pm 0.016 a$ & $0.0439 \pm 0.016 a$ \\
\hline & No of spermatozoa $\left(10^{6}\right)$ & $85.194 \pm 39.278 \mathrm{a}$ & $69.236 \pm 27.251 \mathrm{a}$ & $74.502 \pm 28.848 a$ \\
\hline & Normal spermatozoa (\%) & $48.90 \pm 7.533 \mathrm{a}$ & $57.00 \pm 11.46 \mathrm{a}$ & $53.373 \pm 9.796 a$ \\
\hline
\end{tabular}

*AB =eyestalk ablation; OD0.5 = injection of $0.5 \mathrm{~mL}$ oodev $/ \mathrm{kg} ; \mathrm{OD} 1.0=$ injeksi $1.0 \mathrm{~mL} / \mathrm{kg}$. All values are mean $\pm \mathrm{SD}$. The same letters across columns indicate no significant different mean values $(P>0.05)$ on spermatophore weight data transformed $\sqrt{ }(\mathrm{x}+1)$ and number of spermatozoa transformed $\log _{10}(\mathrm{x})$. 
Table 4. Weight of spermatophore, no.of spermatozoa per spermatophore sac and percentage of normal spermatozoa of tiger shrimp stock post-oodev injection at different times required for spermatophore maturation

\begin{tabular}{|c|c|c|c|c|}
\hline \multirow{2}{*}{$\begin{array}{l}\text { Time required for } \\
\text { spermatophore } \\
\text { maturation }\end{array}$} & \multirow{2}{*}{ Parameter } & \multicolumn{3}{|c|}{ Treatment* } \\
\hline & & $\mathrm{AB}$ & OD0.5 & OD1.0 \\
\hline \multirow{3}{*}{$\mathrm{H}-7$} & Spermatophore weight (g) & $0.0523 \pm 0.009 \mathrm{ab}$ & $0.0449 \pm 0.0154 \mathrm{a}$ & $0.043 \pm 0.0168 \mathrm{a}$ \\
\hline & No of spermatozoa $\left(10^{6}\right)$ & $93.962 \pm 35.329 a$ & $70.983 \pm 29.817 \mathrm{a}$ & $72.425 \pm 31.166 \mathrm{a}$ \\
\hline & Normal sperma (\%) & $46.482 \pm 10.591 \mathrm{a}$ & $53.111 \pm 17.202 \mathrm{a}$ & $51.918 \pm 10.343 a$ \\
\hline \multirow{3}{*}{$\mathrm{H}-14$} & Spermatophore weight (g) & $0.0587 \pm 0.01 \mathrm{a}$ & - & - \\
\hline & No. of spermatozoa $\left(10^{6}\right)$ & $102.613 \pm 23.439$ & - & - \\
\hline & Normal sperma (\%) & $51.87 \pm 6.224 \mathrm{a}$ & - & - \\
\hline \multirow{3}{*}{$\mathrm{H}-21$} & Spermatophore weight (g) & $0.0416 \pm 0.0104 b$ & - & 0.0469 \\
\hline & No. of spermatozoa $\left(10^{6}\right)$ & $43.238 \pm 30.719$ & - & 81.158 \\
\hline & Normal sperma (\%) & $47.200 \pm 4.603 a$ & - & 53.210 \\
\hline
\end{tabular}

of immature sperm cell whereas figure 3C and 3D is the testes with matured spermatozoa.

The histological illustration revealed that the five pairs lobul testes have different stages of seminiferous tubules development, while one pair lobul contained relatively similar tubules (Figure 3C). Stage of these development could be identified by comparing the proportion of the germinal cell and the size of the sperm duct and the number of sperm cell inside the duct (Picture 3B, C, and D). Furthermore, sperm cell inside the testes commonly without spike whereas those existing in MDV have partly completed with spike (Figure 3F) similar to those existed in the spermatophore (Picture $3 \mathrm{H}$ ).

\section{Discussion}

Ablation and oodev injection are basically to manipulate the hormonal system in shrimp. Ablated shrimp lost the sinus gland and organ $\mathrm{X}$ which secrets the gonadal inhibiting hormone (GIH) (Uawisetwathana et al., 2011; Urtgam et al., 2015). Shrimp without GIH due to the ablation lead to the continuously maturation process. As the consequent of the over matured is the slow growth, depleted energy for cell regeneration and health healing, decreased gamet quality and the discarded broodstock making a short time of their usage (Uawisetwathana et al., 2011).

The present study indicated that shrimp injected with OD0.5 produced higher number of males releasing spermatophore compared to $\mathrm{AB}$ and OD1.0. The effect of oodev injection was entirely happened at the maturation stage. On the other word, stimulation of gonadal development through oodev injection resulted in a lower rematuring which was only $14 \%$ and $19 \%$ for OD 0.5 and OD1.0, respectively. Meanwhile, in the AB group percentage of male did the 1 st re-maturing was realtively similar to the 2 nd re-maturing. However, number of male maturing was lower than that of oodev injected males. The low maturing males after ablation compared to oodev injection was also observed in pond-reared tiger shrimp males (Laining et al., 2016). Similarly, it was also reported in wild female tiger shrimp injected with oodev which stimulated spermatophore up to $93 \%$ compared to $60 \%$ in ablated female (Laining et al., 2015). Re-maturation occurred at $\mathrm{AB}$ group found in this experiment showed that the lost of eye stalk caused an inhibiting production of GIH which lead to a continuously maturation process. This phenomenon supported the previous study by Wongprasert et al. (2006) who reported that ablated tiger shrimp can mature and spawn three times continously with a trend of decreasing significantly the hatching rate and survival of nauplii.

Oodev injected males tended to mature once and stimulated a simultaneously spermatophore maturation within 7 days post-injection. This is indicated that the effect of oodev on 

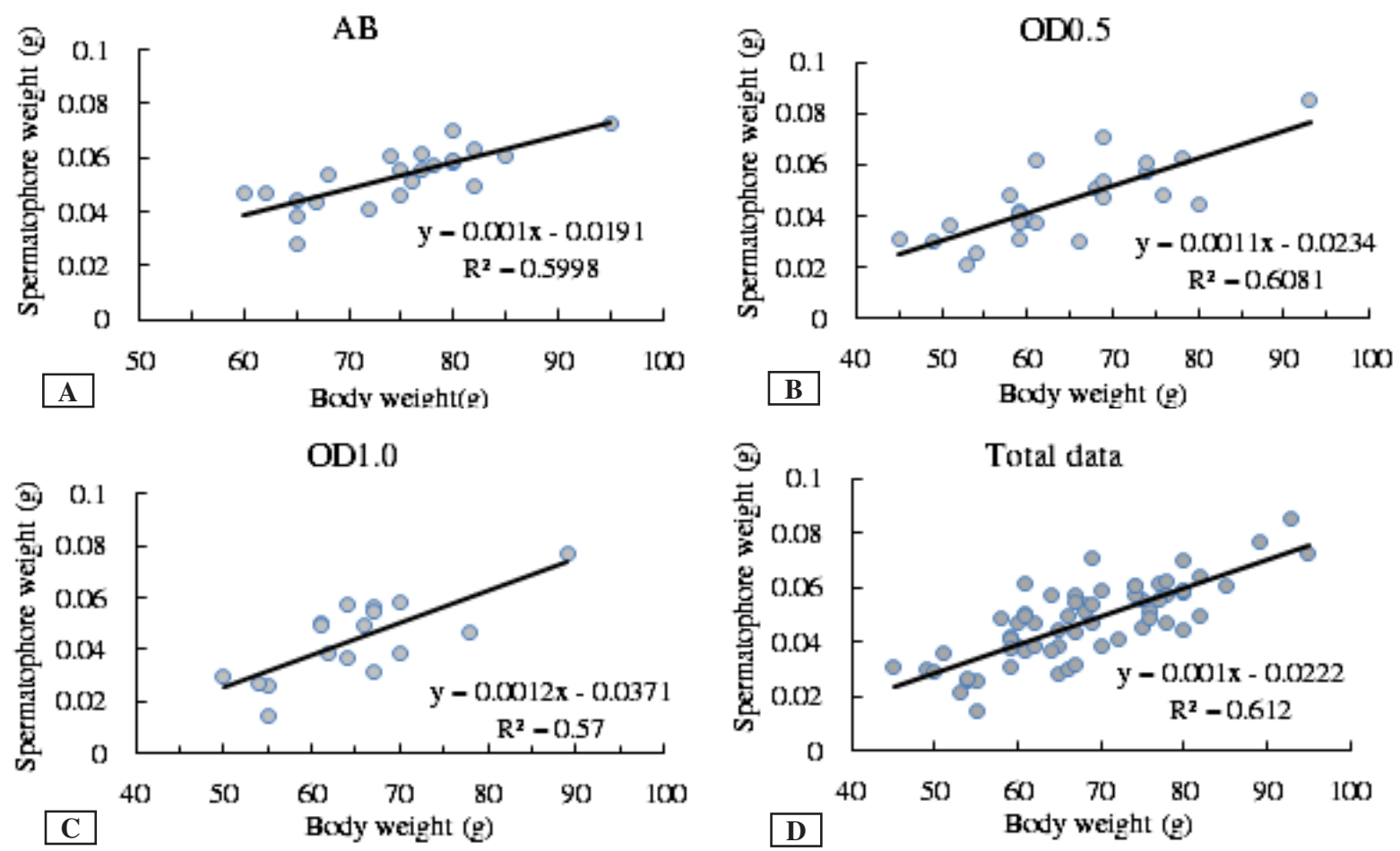

Figure 1. Relationship between body weight and spermatophore weight of tiger shrimp post-injection and ablation and pooled data of all treatments.

Table 5. Proximate composition (\%, air dry) of muscle of males tiger shrimp prior to tretament (H0) and at the end of assessment (H-21)

\begin{tabular}{|c|c|c|c|c|}
\hline \multirow{2}{*}{ Nutrient* } & \multirow{2}{*}{ T0 } & \multicolumn{3}{|c|}{ Treatment** } \\
\hline & & $\mathrm{AB}$ & OD0.5 & OD1.0 \\
\hline Moisture & 6.2 & 9.0 & 5.9 & 6.6 \\
\hline Lipid & 3.1 & 4.3 & 5.8 & 5.5 \\
\hline Crude protein & 78.1 & 73.1 & 72.8 & 76.0 \\
\hline Crude fibre & 0.7 & 0.1 & 0.1 & 0.1 \\
\hline
\end{tabular}

* All analysis were carried-out as simplo $(\mathrm{n}=1) . * * A B=$ eyestalk ablation; OD0.5 = injection of $0.5 \mathrm{~mL} \mathrm{oodev} / \mathrm{kg}$; OD1.0 = injeksi $1.0 \mathrm{~mL} / \mathrm{kg}$

spermatophore maturation occurred within a short time, therefore further application of this hormone is required to stimulate the male to re-mature. Simultaneously spermatophore maturation through oodev injection observed in the present study could support the artificial insemination to increase the fertilization rate of cultured tiger shrimp broodstock. The use of pond-reared tiger broodstock for nauplii production still has several contraints particularly the low mating rate so that application of artificial insemination become very important (Coman et al., 2007; Lante \& Laining, 2016). Since duration of spermatophore to naturally maturate is different between individu, sincronization between spermatophore maturation and the application of artificial insemination can be achieved through oodev injection in particular when a large number of female stocks need to be inseminated.

For the $\mathrm{AB}$ group at the maturation stage, male tiger shrimp required different times for spermatophore maturation (Table 2). This is indicated that hormonal change caused by ablation has different effects on each individual male tiger shrimp. Optic lobe located at eye stalk which was not completely destroyed during ablation was suspected to still produce GIH to some extend so that inhibition of gonadal maturation still occurred (Wongprasert et al., 2006). In contrast, spermatophore maturation in OD0.5 and OD1.0 happened simultaneously and required shorter period within 7 days. This phenomenon showed 

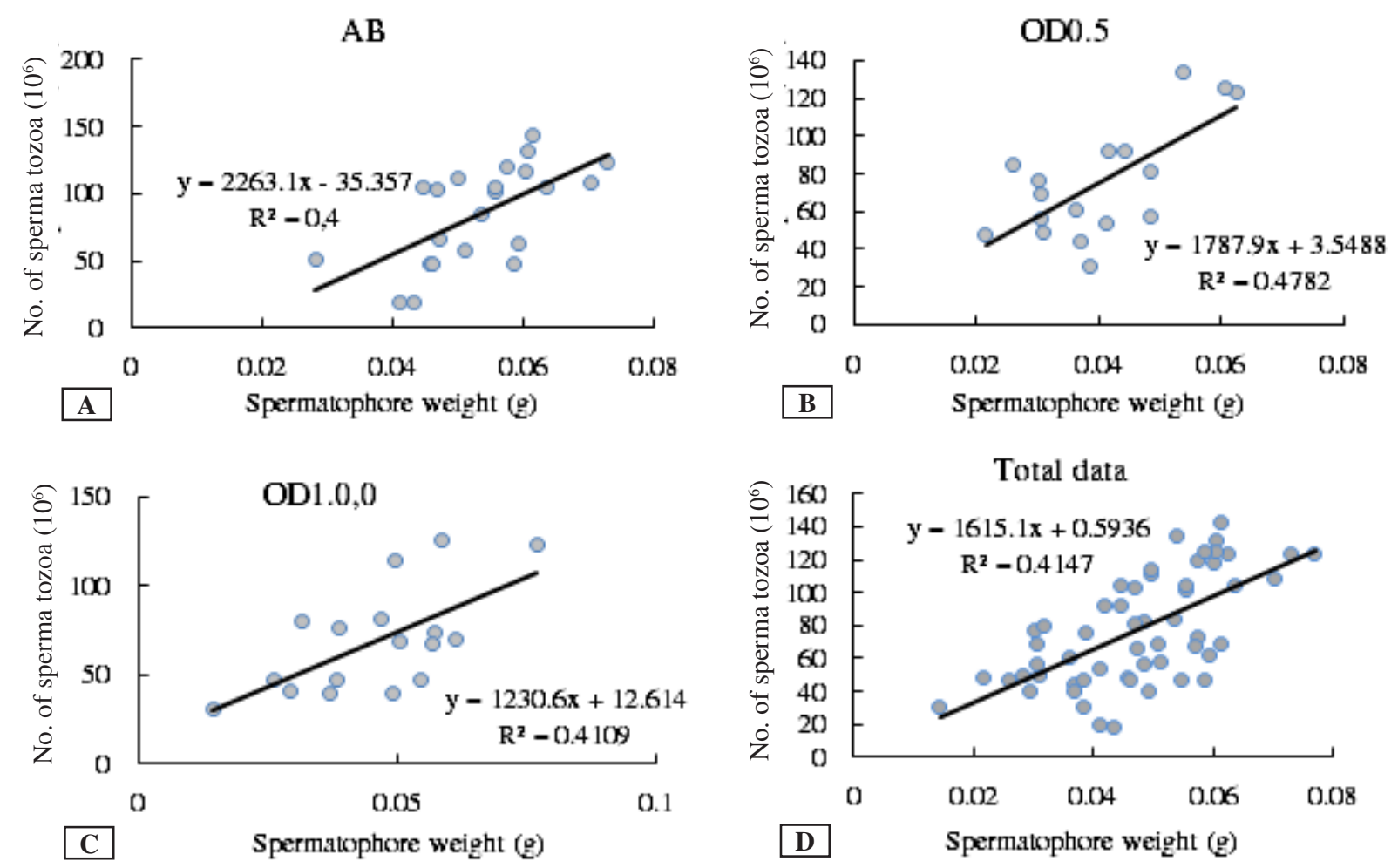

Figure 2. Relationship between spermatophore weight and number of spermatozoa of tiger shrimp post-injection and ablation and pooled data of all treatments.

Table 6. Profile of fatty acid (\% of lipid) in muscle of male tiger shrimp prior to treatments (H-0) and at the end of assessment (H-21)

\begin{tabular}{lcccc}
\hline \multirow{2}{*}{ Parameter } & \multirow{2}{*}{$\mathrm{H}-0$} & \multicolumn{3}{c}{ Treatment* (H-21) } \\
\cline { 3 - 5 } & & $\mathrm{AB}$ & $\mathrm{OD} 0.5$ & OD1.0 \\
\hline Omega 3 & $0.4398 \pm 0.014$ & $0.4553 \pm 0.0143$ & $0.4650 \pm 0.0003$ & $0.4282 \pm 0.0029$ \\
Omega 6 & $0.5318 \pm 0.018$ & $0.3826 \pm 0.0133$ & $0.2020 \pm 0.0008$ & $0.0964 \pm 0.0009$ \\
Omega 9 & $0.3034 \pm 0.009$ & $0.4253 \pm 0.0139$ & $0.3946 \pm 0.0004$ & $0.5111 \pm 0.0018$ \\
Un-saturated fatty acid & $1.3268 \pm 0.045$ & $1.4333 \pm 0.6823$ & $1.3325 \pm 0.0027$ & $1.1869 \pm 0.0025$ \\
Saturated fatty acid & $0.5482 \pm 0.019$ & $0.8267 \pm 0.0238$ & $1.3025 \pm 0.0044$ & $1.4581 \pm 0.0045$ \\
Mono-unsaturated fatty acid (MUFA) & $0.3366 \pm 0.012$ & $0.5772 \pm 0.0190$ & $0.5302 \pm 0.0018$ & $0.6538 \pm 0.0013$ \\
Poly-unsaturated fatty acid (PUFA) & $0.9902 \pm 0.033$ & $0.8561 \pm 0.0279$ & $0.8023 \pm 0.0008$ & $0.5330 \pm 0.0012$ \\
Arachodonic acid (ARA) & $0.1285 \pm 0.005$ & $0.3190 \pm 0.0107$ & $0.2632 \pm 0.0006$ & $0.0037 \pm 0.0002$ \\
Docosahexanoic acid (DHA) & $0.1720 \pm 0.006$ & $0.2500 \pm 0.0081$ & $0.2806 \pm 0.0005$ & $0.2322 \pm 0.0018$ \\
Eicosapentanoic acid (EPA) & $0.2551 \pm 0.008$ & $0.1976 \pm 0.0060$ & $0.1778 \pm 0.0001$ & $0.1841 \pm 0.0000$ \\
Total fatty acid & 1.8749 & 2.2600 & 2.6344 & 2.6449 \\
(C 4:0 - C 24:1) & & & & \\
\hline
\end{tabular}

${ }^{*} \mathrm{AB}=$ eyestalk ablation; $\mathrm{OD} 0.5=$ injection of $0.5 \mathrm{~mL}$ oodev $/ \mathrm{kg}$; OD1.0 $=$ injeksi $1.0 \mathrm{~mL} / \mathrm{kg}$

that oodev injection can stimulate the development of reproductive organ of male tiger shrimp faster than that of ablated males.

Weight of spermatophore, number of spermatozoa and percentage of normal spermatophore were not significantly different among treatments at maturation (Table 3). This is implied that spermatophore maturation through oodev injection can produce spermatozoa with similar quality with those produced by ablation regardless the difference times required for the maturation. For maturation stage, $\mathrm{AB}$ group 


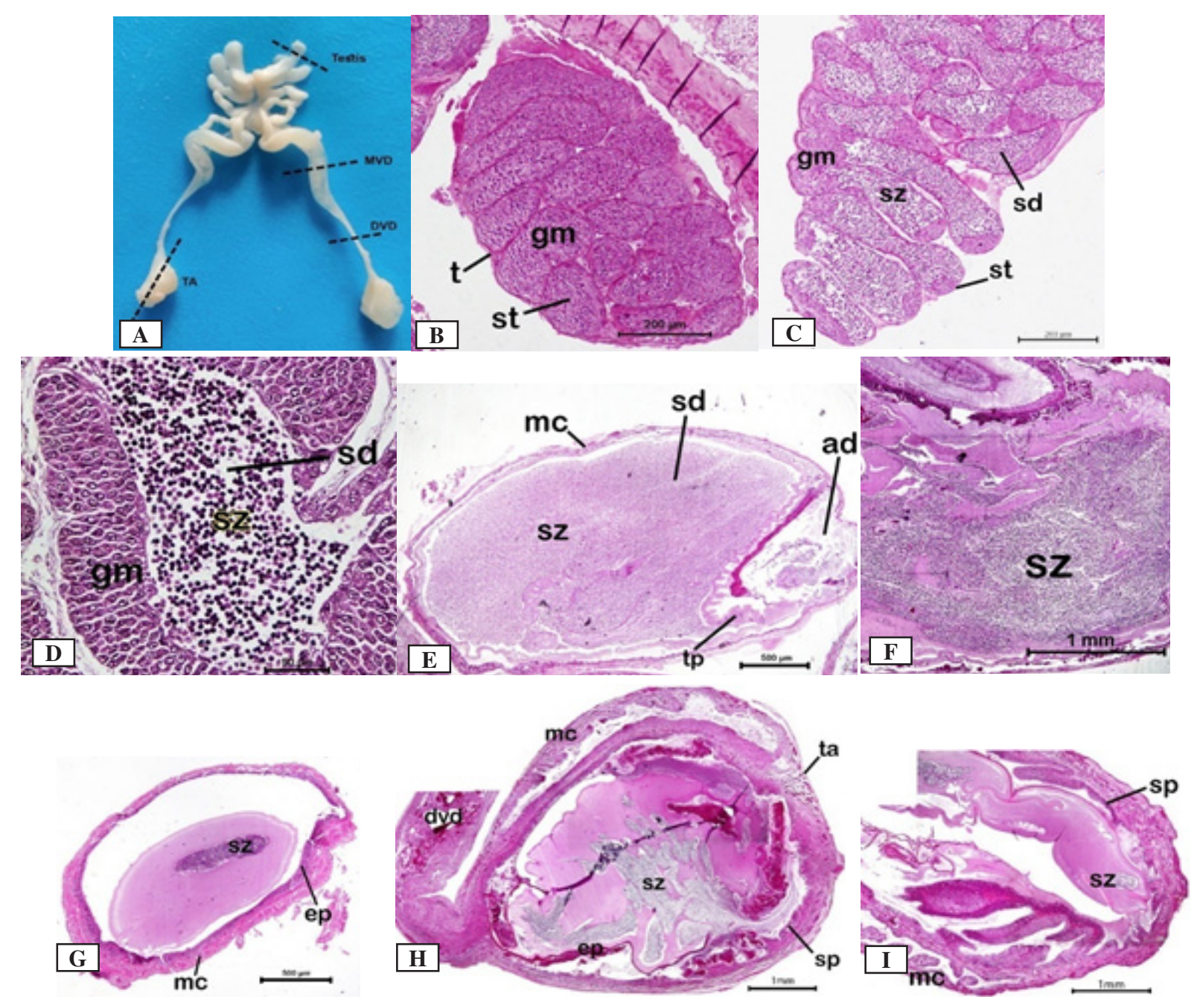

Figure 3. Repoductive organ of male tiger shrimp, Penaeus monodon (A). Light micrograph of ampulla terminale $(B, C)$, testes $(D, E, F)$ and vas deferens $(G, H)$ and distal deferens $(\mathrm{I})$. MVD = median vas deferens; DVD = distal vas deferens; $\mathrm{TA}=$ ampulla terminale; $\mathrm{sz}=$ spermatozoa; $\mathrm{ep}=$ epitelium; $\mathrm{sp}=$ spermatofor; $\mathrm{mc}=$ muscular; $\mathrm{t}=$ testes; $\mathrm{st}=$ seminiferous tubules; $\mathrm{gm}=$ germinal; $\mathrm{sd}=$ seminiferous duct; $\mathrm{tp}=$ typhlosole; ad = accessory duct.

produced heavier spermatophore at $\mathrm{H}-7$ and $\mathrm{H}-14$ compared to spermatophore released at $\mathrm{H}-2$. However, number of normal spermatozoa was not different for the three maturation periods indicating that re-maturation in ablated males might reduce a certain aspect of the spermatophore quality

The $\mathrm{R}^{2}$ values for the linear regression between body weight and spermatophore weight at the three groups were relatively similar and the $\mathrm{R}^{2}$ for total data was 0.612 . The $\mathrm{R}^{2}$ value detected in the present study implied that dependent variable of male body weight affected the independent variable of spermatophore weight meaning that the bigger size of the male shrimp, the bigger its spermatophore. In contract, no positive relationship between spermatophore weight and number of spermatozoa produced with the low $\mathrm{R}^{2}$ value which was 0.4147 . Similarly, it was found by Meunpol et al. (2005) who concluded that no relationship between spermatophore weight and number of spermatozoa cell or correlation between these two variables was low (Jiang et al., 2009). The low $R^{2}$ value also impiled that there is an independent variable influenced the number of spermatozoa such as nutrition (Braga et al., 2013; Leelatanawit et al., 2014). In addition, weight of spermatophore is not only afftected by the sperm cell mass but only by the intermediated acellular secreted by vas deferens (Diwan \& Josep, 2009).

Ablation is a technique to destroy the optic lobe which can negatively affect the physiological process besides reproduction while hormonal injection does not largely affect the physiological process due to the specific targeted organ (Wongprasert et al., 2006). Molecular assessment indicated the change of gen expression on 
the metabolism pathway on ablated shrimp (Uawisetwathana et al., 2011). Total fatty acid in muscle of $\mathrm{AB}$ group was lower than that of oodev injected males indicating the metabolism change due to the lost of several secretion glands and nervous system after ablation. The main effect of ablation on reproduction is the lipid transport from hepato-pancreas to gonad associated with depletion of GIH level in sinus gland. The lipid transport is also associated with the elevation of several lipid classes in hemolymph (SainzHernández et al., 2008). Increasing of total fatty acid in muscle has been also detected on cultured male tiger shrimp injected with sGnRH-a compared to ablated shrimp (Laining et al., 2016).

Testes contained immature sperm cells indicated by undeveloped spike at the anterior of the spermatozoa. The pattern of spermatozoa development observed in the present tudy was relatively similar to that found on giant freshwater shrimp, Macrobrachium rosenbergii (Okumura, 2004), lobster, Nephrops norvergicus (Rotllant et al., 2012) and white shrimp, Litopenaeus schmitti (Fransozo et al., 2016). Based on morphological observation on spermatozoa cell, it was also identified undeveloped spikespermatozoa inside spermatophore. Leelatanawit et al. (2014) stated that spermatozoa of tiger shrimp has still developed in vas deferens before reaching spermatophore. Based on histological observation it showed that oodev stimulation did not negatively affect the anatomy of reproductive organ of male tiger shrimp.

\section{CONCLUSION}

Oodev injection at $0.5 \mathrm{~mL} / \mathrm{kg}$ of wild male tiger shrimp produced higher number of male releasing spermatophore of $84 \%$ compared to ablated which was $68 \%$. Simultaneously gonad maturation of male tiger shrimp could be stimulated by oodev injection which also shorten the time of the maturation.

\section{ACKNOWLEDGEMENT}

This study was funded by DIPA APBN 2016 of Research Institute for Brakishwater Aquaculture and Fisheris Extention (RIBAFE). The authors thank to the researchers ((Ike Trismawanti and Muhammad Chaidir Undu) and the technicians (Wendy, Umar and Ramadhan) of Barru Installation of Tiger Shrimp Hatchery of (RIBAFE) for their assistances during the study.

\section{REFERENCES}

Akbar F, Sudrajat AO, Subaidah S, 2015. Sperm quality of Litopenaeus vannamei broodstock injected by PMSG and antidopamine. Jurnal Akuakultur Indonesia 14: 98-103.

AOAC International. 1999. Official Methods of Analysis. $16^{\text {th }}$ edn. Association of Official Analytical Chemists International. Maryland, USA: Gaithersberg.

Arnold SJ, Coman GJ, Burridge C, Rao M. 2012. A novel approach to evaluate the relationship between measures of male fertility and egg fertilization in Penaeus monodon. Aquaculture 338-341: 181-189.

Babu KN, Pallavi PN, Reddy DC, Kumar NVN. 2013. Ovarian maturation and spawning in the tiger shrimp. Penaeus monodon by serotonin and dopamine injection. International Journal of Pharmacy \& Life Sciences 4: 2785-2793.

Braga AL, Lopes DLA, Poersch LH, Wasielesky JrW. 2013. Spermatophore and sperm quality of the pink shrimp Farfantepenaeus paulensis fed with fresh food supplemented with pollen and paprika. Aquaculture 380-383: 29-32.

Chang CC, Wu ZR, Chen CS, Kuo CM, Cheng W. 2007. Dopamine modulates the physiological response of the tiger shrimp Penaeus monodon. Aquaculture 270: 333-342.

Coman GJ, Arnold SJ, Peixoto S, Crocos PJ, Coman FE, Preston NP. 2006. Reproductive performance of reciprocally crossed wildcaugh and tank-reared Penaeus monodon broodstock. Aquaculture 252: 372-384.

Coman GJ, Crocos PJ, Arnold SJ, Keys SJ, Murphy B, Preston NP. 2007. Growth, survival and reproductive performance of domesticated Australian stocks of the giant tiger prawn. Penaeus monodon reared in tanks and raceways. Journal of World of Aquaculture Society 36: 464-479.

Diwan AD, Joseph S. 2009. Cryopreservation of gametes. In: Diwan AD. Joseph S. Ayyappan S (ed). Physiology of Reproduction. Breeding and Culture of Tiger Shrimp. Penaeus monodon (Fabricius) First edition. Delhi. India: Narendra Publishing House.

Dufour S, Sebert ME, Weltzien FA, Rousseau K, Pasqualini C. 2010. Neuroendocrine control by dopamine of teleost reproduction. Journal of Fish Biology 76: 129-160.

Fransozo V, Fernandes AB, Lopez-Greco LS, Zara FJ, Santos DC. 2016. Functional morphology of the male reproductive system of the white 
shrimp Litopenaeus schmitti compared to other Litopenaeus. Invertebrate Reproduction and Development 60: 161-174.

Hafez ESE, Hafez B. 2000. Reproduction in Farm Animal, Ed ke-7. Philadelphia, Pennsylvania: Lappicod Williams \& Wilkins.

Huang H, Ye H, Li S, Wang G. 2008. Immunocytological evidence for the presence of vertebrate FSH and LH-like substances in the brain and thoracic ganglion of the swimming crab. Portunus trituberculatus. Progress in Natural Science 18: 1453-1457.

Jiang SG, Huang JH, Zhou FL, Chen X, Yang QB, Wen WG, Ma ZM. 2009. Observations of reproductive development and maturation of male Penaeus monodon reared in tidal and earthen ponds. Aquaculture 292: 121-128.

Laining A, Usman, Syah R. 2014. The use of seaworm meal in maturation diet as partial substitution of fresh diet for pond reared tiger shrimp broodstock. Jurnal Akuakultur Indonesia 9: 123-132.

Laining A, Lante S, Usman. 2015. Induce of gonadal maturation and improvement of egg fertilization rate of female broodstock tiger shrimp, Penaeus monodon through hormonal induction without eyed ablation. Jurnal Riset Akuakultur 10: 61-68.

Laining A, Usman, Syah R. 2016. Induction of gonadal maturation of pond cultured male tiger shrimp. Penaeus monodon with different dosages of gonadotropin releasing hormone analogue against eye stalk ablation. Indonesian Aquaculture Journal 11: 23-30.

Lante S, Laining A. 2016. Application of artificial insemination for wild tiger shrimp, Penaeus monodon with different sources and numbers of spermatophore. Jurnal Riset Akuakultur 11: 271-280.

Leelatanawit R, Uawisetwathana U, Khudet J, Klanchui A, Phomklad S, Wongtripop S, Angthoung P, Jiravanichpaisal P, Karoonuthaisiri N. 2014. Effects of polychaetes Perinereis nuntia on sperm performance of the domesticated black tiger shrimp Penaeus monodon. Aquaculture 433: 266-275.

Marsden G, Hewitt D, Boglio E, Mather P, Richardson N. 2008. Methyl farnesoate inhibition of late stage ovarian development and fecundity reduction in the black tiger prawn. Penaeus monodon. Aquaculture 280: 242-246.

Marsden G, Richardson N, Mather P, Knibb W. 2013. Reproductive behavioural differences between wild-caught and pond-reared Penaeus monodon prawn broodstock. Aquaculture 402-403: 141-145.

Meunpol O, Meejing P, Piyatiratitivorakul S. 2005. Maturation diet based on fatty acid content for male Penaeus monodon broodstock. Aquaculture Research 36: 1216-1225.

Nainggolan A, Sudrajat AO, Utomo NBP, Harris E. 2014. Ovarian maturation in Asian catfish Clarias sp. by combination oodev and nutrition addition Spirulina planThesis. International Journal of Sciences: Basic and Applied Research 15: 564-583.

Okumura T. 2004. Perspectives on hormonal manipulaiton of shrimp reproduction. Japan Agricultural Reearch Quarterly 38: 49-54.

Pratoomchat B, Piyatiratitivorakul S, Menasveta P. 1993. Sperm quality of pond-reared and wild-caught Penaeus monodon in Thailand. Journal of the World Aquaculture Society 24: 530-540.

Rotllant G, Chiva M, Durfort M, Ribes E. 2012. Internal anatomyand ultrastructure of the male reproductive system of theNorway lobster Nephrops norvegicus (Decapoda: Astacidea). Journal of Morphology 273: 572-585.

Sainz-Hernandez JC, Racotta IS, Dumas S, Hernandez-Lopez J. 2008. Effect of unilateral and bilateral eyestalk ablation in Litopenaeus vannamei male and female on several metabolic and immunologic variables. Aquaculture 283: 188-193.

Sudrajat AO, Sugati A, Alimuddin. 2014. Induced maturation of eel Anguilla bicolor using different hormone combination. Jurnal Akuakultur Indonesia 12: 189-201.

Sukthaworn S, Panyim S, Udomkit A. 2013. Molecular and functional characterization of a dopamine reseptor type1 from Penaeus monodon. Aquaculture 380-383: 99-105.

Tinikul Y, Mercier AJ, Soonklang N, Sobhon P. 2008. Changes in the levels of serotonin and dopamine in the central nervous system and ovary. and theirpossible rolesin the ovarian development in the giant freshwater prawn. Macrobrachium rosenbergii. General and Cimparative Endocrinology 158: 250-258.

Tinikul Y, Poljaroen J, Tinikul R, Anuracpreeda P, Chotwiwatthanakun C, Senin N, Poomtong T, Hanna PJ, Sobhon P. 2014. Effects of gonadotropin-releasing hormones and dopamine on ovarian maturation in the Pacific white shrimp, Litopenaeus vannamei and their presence in the ovary during ovarian 
development. Aquaculture 420-421: 79-88.

Uawisetwathana U, Leelatanawit R, Klanchui A, Prommoon J, Klinbunga S, Karoonuthaisiri N. 2011. Insights into eyestalk ablation mechanism to induce ovarian maturation in the black tiger shrimp. PloS ONE 6: e24427.

Urtgam S, Treerattrakool S, Roytrakul S, Wongtripop JP, Panyim S, Udomkit A. 2015. Correlation between gonad-inhibitng hormone and vitellogenin during ovarian maturation in the domesticated Penaeus monodon.
Aquaculture 437: 1-9

Wongprasert K, Asuvapongpatana S, Poltana P, Tiensuwan, M. Withyachumnamkul B. 2006. Serotonin stimulates ovarian maturation and spawning in the black tiger shrimp Penaeus monodon. Aquaculture 261: 1447-1454.

Ye H, Huang H, Wang G, Li S. 2009. Occurrence of gonadotropins like substances in the thoracic ganglion mass of the mud crab, Scylla paramamosain. Acta Oceanologica Sinica 285: 76-80. 